tion of some $\$ 500,000$ was such a circumstance as demanded investigation; but in any event this circumstance can not be considered apart from the fact that twenty assurances by the auditor had antedated it. And this circumstance has no bearing on the question of the auditors' responsibility for earlier payments.

It is believed that the treatment of such cases as this as sounding in tort for negligent injury is to be explained in part as a survival from the ancient misfeasance cases and in part as mere "mechanical jurisprudence". He who contracts to render services is bound to exercise the care and skill of the ordinary prudent member of his profession or calling. This looks like "the care of the reasonably prudent man under the circumstances" and such it probably is. But the use of this label has led to the application in many of these cases of the familiar doctrine of contributory negligence, and this is undesirable. "Due care", to most minds, lay and legal, carries the concept of active vigilance. This should not be required of the plaintiff contractee. That "objective good faith"- the rule here contended for-is in the light of careful analysis really "due care under the circumstances", is no excuse for submitting to the jury, without more, the question of the contractee's contributory negligence. 3 The jury need the guidance of a rule of more definite content-a rule that will emphasize and take into account, as did the ancient misfeasance actions, the misleading behavior of the contractor.

\title{
THE NEW YORK COURT OF APPEALS AND PLEADING
}

Perhaps a single regret may accompany the passing of common law pleading:- that there also passed the "special pleader". This type of lawyer has always been reputed to possess great ability. At least he had a keen interest in and enthusiasm for the study of pleading. Now we are met with the seeming paradox that often the abler the lawyer, the less enthusiasm he has for pleading problems. An excellent example of this is to be found in the attitude of the New York Court of Appeals towards code

24 “. . . the featureless generality, that the defendant was bound to use such care as a prudent man would do under the circumstances, ought to be continually giving place to the specific one, that he was bound to use this or that precaution under these or those cireumstances. The standard which the defendant was bound to come up to vas a standard of specific acts or omissions, with reference to the specifie circumstances in which he found himself. If in the whole department of unintentional wrongs, the courts arrived at no further utterance than the question of negligence, and left every case, without rudder or compass, to the jury, they would simply confess their inability to state a very large part of the law which they required the defendant to know, and would assert, by implication, that nothing could be learned by experience." Holmes, Tho Conmon Law (1881) 111. 
pleading. That court has always ranked as one of the ablest tribunals in the country, and the reputation of its present personnel is justly as high as at any time in its history. Yet clearly the court has no consistent theory of the function of pleading in the modern judicial system. Its early hostility to the infant code is well known. Thereafter more liberal views intermittently prevailed. But in comparatively recent years there has been a retrogression to ancient technicalities, particularly in the attempted resurrection of distinctions between law and equity. ${ }^{1}$ Nevertheless, the passage in 1920 by the legislature of the Civil Practice Act and the attempt of the court to give effect to the more liberal provisions as to joinder of parties in that Act led again to a broadening of some of the pleading concepts held by the court, notably that of the cause of action. ${ }^{2}$ Now in its latest pronouncement there has again been a most violent reaction towards the past.

In Ader v. Blau (1925) 241 N. Y. 11, the plaintiff, suing to recover damages for the death of his intestate, a young boy, set up two counts: in one, charging that the first defendant had negligently maintained an iron picket fence, upon which the intestate had been injured in a manner causing infection and death; and, in the other, alleging that the intestate, being injured by a picket fence, came to the second defendant as a physician and surgeon for treatment and was so negligently treated by the latter that solely by reason thereof he died. The court held, Cardozo, J., dissenting, that the joinder was improper. ${ }^{3}$

It will be seen that the situation was the not unusual one where the plaintiff was in doubt as to just what the proof at the trial would disclose. He felt that he had a possible claim against either or both of the defendants and he desired to lay the whole case before the court and let it decide. Why is this not socially desirable? Instead of two cases with much of the testimony identical there is only one, and the time of courts, of litigants, and of the witnesses-a most meritorious but little considered classis saved. The court, however, does not approach the case from this angle. It begins its discussion by saying that if the joinder is permissible, "a step has been taken away from prior rules of practice and procedure which will be regarded as a long and

\footnotetext{
1 See Clark, The Union of Law and Equity (1925) 25 Cor. L. Rev. 1; COMMENTS (1923) 32 YALE LAW JOURNAL, 707.

2 See Cleveland Cliffs Iron Works v. Keusch (1923) 237 N. Y. 533, 143 N. E. 731; and discussion in Clark, The Code Cause of Action (1924) 33 YaLe Law JounNal, 817. Cf. Sherlock v. Manwaren (1924, 4th Dopt.) 208 App. Div. 538, 203 N. Y. Supp. 709. For the joinder of 193 plaintiffs who claimed to have been deceived by the same false prospectus of stock, see Akely v. Kinnicutt (1924) 238 N. Y. 466, 144 N. E. 682, and CoMmENT's (1924) 34 YANE LAW JouRNAX, 192.

3 Reversing Ader v. Blau (1925, 2d Dept.) 211 App. Div. 532, 209 N. Y.
} 
conspicuous one, even in these times when the desire for procedural reform and improvement has become strong, widespread and fruitful." After this illuminating disclosure of its emotional reaction to new pleading situations it continues: "Of course, we ought not to be led into taking it even under the alluring desire for progress and improvement if it is forbidden by controlling rules and statutory provisions." It is submitted that there are no such controlling rules and provisions.

Apparently the court's difficulty came from the fact that the legislature, in adopting the liberal English rules as to joinder of parties in the Civil Practice Act of 1920, failed to remove the old shackles as to joinder of causes of action." Thus persons may be joined as plaintiffs where "if such persons brought separate actions any common question of law or fact would arise"; " persons may be joined as defendants "against whom the right to any relief is alleged to exist, whether jointly, severally, or in the alternative"; ${ }^{\circ}$ and further, a plaintiff in doubt as to the persons rrom whom he is entitled to redress, may join two or more, "to the intent that the question as to which, if any, of the defendants is liable, and to what extent, may be determined as between the parties".' But causes of action, in order to be joined, must still be "consistent with each other" and must fall within one of the arbitrary classes of the statute, including the famous one of "claims arising out of the same transaction or transactions connected with the same subject of action". ${ }^{8}$ The modern tendency is to do away with those ambiguous restrictions. ${ }^{9}$ Yet a liberal interpretation of them, viewing them, and in fact the entire subject of pleading, from the functional standpoint, would malie of them usable concepts. The court had previously given occasion

Supp. 784 (two justices dissenting), which in turn had reversed the Special Term.

4 The opportunity thus afforded for confusion was discussed in CosiMEENTS (1923) 32 YALE LAW JOURNAL, 384.

5 N. Y. C. P. A., 1921, sec. 209.

${ }^{\circ}$ N. Y. C. P. A., 1921, sec. 211; continuing that "judgment may be given against such one or more of the defendants as may be found to be liable, according to their respective liabilities." Sec. 212 states that it is not neeessary that "each defendant shall be interested as to all the relief prayed for, or as to every cause of action included in any proceeding against him." For joinder of parties alternately responsible, see (1924) 33 YALE LAW Journal, 328, (1925) 35 YALE LAW JOURNAL, 113.

IN. Y. C. P. A., 1921, sec. 213. The court says: "It is not claimed that section 213 covers this action." One may be permitted to wonder why. Was it because of the mere form of the complaint? See discussion of the form of the complaint, infra.

${ }^{8}$ N. Y. G. P. A., 1921, sec. 258 . Miany codes do not contain the express requirement of consistency.

${ }^{9}$ In England and in some of the states restrictions on joinder of causes have been substantially removed. CoMments (1923) 32 YALE LAW JounNAL, 384; Sunderland, Joinder of Actions (1920) is MIICE. L. RET. 571. 
to hope that such was its point of view..$^{10}$ That hope is shattered by the present case. Here the court holds (a) -inferentiallythat there are more than one cause of action, (b) that the causes are inconsistent, (c) that they do not arise out of the same transaction or transactions connected with the same subject of action, (d) that-probably - the common question of law or fact test does not apply to the joinder of defendants, ${ }^{12}$ (e) that there is no stuch common question here, and (f) that the defendants are not responsible "jointly, severally, or in the alternative". With each one of these conclusions the writer disagrees. ${ }^{12}$

How should the somewhat vague provisions of the original code be interpreted? The answer should be made only after the function of pleading in the trial of a case is determined. The com. mon law writ system was, as is well known, really a corollary, or perhaps an embodiment, of the substantive law of the time. There was no right without a writ. The pleadings, therefore, worked out in advance of the trial the law of the case. If the plaintiff's lawyer misinterpreted the law, that was the plaintiff's misfortune. The plaintiff was expected to foresee the form in which the testimony at the trial would develop, to know the applicable law, and to act accordingly. The procedural reform of the nineteenth century was a reaction against this harsh system. For it was substituted the pleading of the facts. No longer was the plaintiff required to give the exact legal label applicable to his case; he was only expected to give, in advance of the trial, his

10 See supra note 2.

11 This suggestion is contrary to the view ably expressed by Crouch, J., in Sherlock v. Manwaren, supra note 2, and seems contrary to the English experience, where the extension of the privilege of joining plaintifis has resulted in the decisions in a like extension as to defendants. See Payno $v$. British Time Recorder Co. [1921, C. A.] 2 K. B. 1; Eng. Ann. Prac. 1924, 224-226; Comments (1923) 32 YaLE IAW Journat, 384, 386. But seo (1924) 24 CoL. I. REv. 681. It is true that the test is expressly strated only in the section on joinder of plaintiffs. But the joinder of defendants is stated substantially without restriction (N. Y. C. P. A., 1921, sec. 211); and hence if the test does not apply, surely a broader, rather than n narrower rule, as intimated by the court, must apply. But the absence of $a$ stated restriction would render applicable the general theory of trial convonience as the controlling test. This principle comes from the equity rules of joinder which were adopted generally by the codifiers. Trial convonience would largely turn on such points as whether the testimony of tho witnesses against each defendant separately would overlap; and hence, in substance, we are back to our "common question of law or fact" test, probably as good a statement of the rule as we can make. Furthermore, the defendants must of necessity be those who claim adversely to the plaintiffs and, as the English experience shows, it seems impossible to determine ono set of parties without recourse to the methods of determining the other set.

12 In the limited space here available an extended discussion of each point is not possible. It is believed, however, that the writer's position has beon made clear in the articles cited supra. 
best idea of how the past happenings which brought him into court had occurred. After the trial had definitely established the facts, the court was to give the proper legal judgment. Furthermore, pleading was to be relegated to the position of an aid to the administration of justice, instead of being an end in itself. And hence we have our modern conception of the function of pleading, with particular emphasis upon its effect on the efficient conduct of court business.

The change in attitude towards joinder of parties illustrates this trend. At common law, joinder was only permissible where the substantive right was viewed as joint, as in the case of joint obligations or joint torts. Joinder as a purely procedural device to act as a short-cut in litigation was not contemplated at common law. It came in, however, from the equity procedure with the adoption of code pleading; and it is now being extended, as witness the Civil Practice Act. Hence it seems curious in the present case to find the court going back to the old rules determining what are joint torts and who are joint tort ieasors to justify its decision. ${ }^{13}$

If then this functional aspect of pleading is considered, the purpose of the pleadings is no longer to notify the court of the legal labels involved but to give fair notice of the facts considered as the ground of suit, and of as many facts as may be efficiently litigated as a single suit. In the principal case we have the question, how many causes of action are there presented? The court thinks of the legal labels to be applied in deciding the case and says, two, one for the negligence or nuisance of the owner, one for the malpractice of the physician.1" Yet the non-legal witnesses are not going to divide up their testimony along those lines. They are there to tell what they know concerning the facts leading to the death of the child. This is the ground or oceasion of the suit, and hence, in the practical and lay sense, is the cause of action. Since pleading is to give a foretaste of the facts which in turn come from lay witnesses, and since it is the shortening of trials, rather than instruction of the court in the process of legal labelling which the pleadings are designed to assist, the latter is the proper content for the phrase in this connection..$^{15}$

Similar principles apply to the other terms considered in the opinion. The court, thinking of the different rights of action against each defendant, holds there is no common question of law

${ }^{13} C f$. (1925) 34 YALE LAT JouRNaL, 335. The discussion was made in connection with the holding that inconsistent causes of action were stated.

14 These express labels are used by the dissenting justices below. Seo supra note 3.

${ }^{15}$ See Clark, loc. cit. supra note 2. Professor MicCaskill, however, believes that a more legalistic definition should be given to the concept cause of action; he, too, favors the lay definition of transaction and transactions connected with the same subject of action. MrCaskill, Actions and 
and fact; and yet the practical reason for the form in which the suit is brought is that the plaintiff is not sure who cansed the death of the child. Likewise the court holds that there is more than one (legal) transaction, and more than one subject of the action, to wit, the separate negligence of each defendant. It is true that this legalistic, rather than lay or practical definition, was the one made in certain early New York cases; but these have been so far neglected in the later cases that their resurrection is unexpected; and they have been definitely repudiated by other courts and in other codes..$^{16}$ And finally the same explanation holds of the big bugaboo to the court in the case, the requirement of consistent causes of action. Here is no necessary inconsistency in the facts as the lay witnesses will tell them; there is only an inconsistency of legal theories. ${ }^{17}$ Proof of the facts constituting one of the counts will not necessarily show that the other is not true (unless perchance the case is made to turn wholly on the use of the word "solely" in the second count). ${ }^{\text {ts }}$ This is the only true basis of inconsistency, as the courts have come to see, not only in connection with inconsistent causes of action, ${ }^{10}$ but also with inconsistent defenses, where the experience has been extensive and decisive. ${ }^{20}$ Moreover, under the new provisions the

Causes of Action (1925) 34 Yale Law Journal, 614. See also Commen'ts (1925) 34 YALE LAW JOURNAL, 879.

${ }^{16}$ See complete discussion by McCaskill, op. cit. supra note 15 , at 643 , 648; Comments (1924) 33 YALE LaW Journat, 862. Compare, e. g., Kcep v. Kaufman (1874) 56 N. Y. 332, with the cases in note 2, supra. See also Payne v. N. Y. S. \& W. R. R. (1911) 201 N. Y. 436, 95 N. E. 19; Franco \& Canada Steamship Co. v. Berwind (1920) 229 N. Y. 89, 127 N. E. 893. For code provisions contrary to the principal case, see Conn. Prac. Bls. 1922 , secs. 172,187 , at 282,286 ; Craft Refrigerating Co. v. Quinnipiac Brewing Co. (1893) 63 Conn. 551, 29 Atl. 76; Sheen's N. J. Prac. Act, 1916, sec. 307, 222. Compare also Harris v. Avery (1869) 5 Kan. 146; Scarborough v. Smith (1877) 18 Kan. 399; McArthur v. Moffett (1910) 143 Wis. 564, 128 N. W. 445; Scott v. Waggoner (1914) 48 Mont. 536, 139 Pac. 454; Shaffer v. Chicago, R. I. \& P. R. R. (1923) 300 Mo. 477, 254 S. W. 257; Van Meter v. Goldfarb (1925, III.) 148 N. E. 391.

17 The court does not cite authority on this point; it says, "It seems too clear for debate that such contradictory and repugnant theories cannot be consistent and that plaintiff at this point fails to sustain his complaint."

18 The form of the complaint is discussed, infra.

19 Cardozo, J., dissenting, properly says: " the two causes of action aro, therefore, not inconsistent, since proof of the one will not exclude the other, but both may coexist." See France \& Canada S. S. Co. v. Berwind, supra note 16; Joannes Bros. Co. v. Lamborn (1923) 237 N. Y. 207, 142 N. E. 587. There is also a good discussion in Sieflin v. Erie R. R. (1908, Sup. Ct. Spec. T.) 57 Misc. 222, 107 N. Y. Supp. 1060; Seiter v. Bischoff (1895) 63 Mo. App. 157; Rinard v. O. K. C. \& E. R. R. (1901) 164 Mo. 270,64 S. W. $124 ;$ Astin v. Chicago etc. R. R. (1910) 143 Wis. 477,128 N. W. 265; (1911) 31 L. R. A. (N. S.) 158, note.

20 See Comments (1921) 1 OR. L. REv. 26; (1922) 10 CALIF. L. REv. 251; (1917) 1 MINN. L. REv. 94. As showing the liberal development, of. 
plaintiff may make alternative claims against different defendants. The effect of the court's logic would be to wipe out of the statute the provision permitting the suing of defendants alternatively responsible. ${ }^{21}$ By this strict construction the new statue does not amend the old; quite the contrary.

It would seem, therefore, that the plaintiff has shown a proper case for the application of the new provisions as to joining defendants. ${ }^{22}$ True, it would have been more artistic for him to have told his story in numbered paragraphs in a single count and asked the court specifically to determine the responsibility of each deferdant." This would have indicated more directly his reliance on these statutes. Yet in view of the confusion of the New York cases on this matter of the use of separate counts, he ought not ti be criticised on the score of form alone. $\approx$ The main point is that there is no possible doubt of his position, and a rewriting of the complaint could not the more clearly inform the court and counsel that he wishes to hold one or both of the two defendants for the child's death. The case should not even have been revers $\epsilon$ U for the correction of the pleading, much less for the dropping of one of the defendants.

Had the court contented itself with holding the joinder inconvenient on the facts, comparatively little harm would have been done. But the wording and tone of the opinion must nesessarily

Derby v. Gallup (1860) 5 Minn. 119, with MeAlpine v. Fidelity \& Casualty Co. (1916) 134 Minn. 192, 158 N. W. 967. For the early confusion in Nev York, see the cases cited in Derby v. Gallup; the liberal rule has long prevailed, Bruce v. Burr (1876) 67 N. Y. 237.

21 See supra note 6. The court has apparently recognized joinder in the alternative in Zenith Bathing Pavilion, Inc. a. Fair Oals S. S. Corp. (1925) 240 N. Y. 307,148 N. E. 532, citing some of the lower court decisions.

22 Sherlock $v$. Manwaren, supra note 2 (several doctors who successively set the plaintiff's arm, may be joined in an action for damages; this excellent decision would, it seems, not be sustainable under the instant case) ; Cowles v. Eidlitz \& Son, Ince. (1923, Sup. Ct. Spec. T.) 121 Misc. 340, 201 N. Y. Supp. 254; Notes (1924) 24 Cor. L. Rev. 208; Bullocls v. L. G. O. Co. [1907, C. A.] 1 K. B. 361 and Bcrlcmanan v. British Hotor Cab Co., Ltd., [1914, C. A.] 3 K. B. 181 (collision cases to determine which defendant is responsible); Compania Sansinenza a. Houlder Brós. [1910] 2 K. B. 35A; Re Becli; Attia v. Seed (1918, C. A.) 118 L. T. 629; Pagme v. British Time Recorder Co., supra note 11; Eng. Ann. Prac., 1924, 0. 16, r. 4, 7, and notes, pp. 224-229, 230, 231; (1907) 51 SoL. Jour 275; ef. Davis v. Groner (1923, N. J.) 121 Atl. 446.

23 The confusion is discussed in Clark, loc. cit. supra note 2 . See also supra note 15. For example, in the case of Heapby v. Eidlitz (1921, 1st Dept.) 197 App. Div. 455, 189 N. Y. Supp. 431, the plaintiff made alternative allegations against the defendant-a practice permissible under the more liberal codes, (1924) 34 YALE LAW JouRNal, 103; and the court pocr Page, J., reached the surprising result that there were two causes of action stated which were inconsistent and that therefore they must be separately stated. 
have the most baleful effect upon the lower New York courts, most of whom, unfortunately, needed no spur towards pleading legalism. ${ }^{24}$ The harm of such a decision is not limited to the particular case; it will continue long after this litigation, now so unnecessarily to be lengthened, has at length been ended. It will continue in fact until it is either overruled by the court or legislature; for that, it is confidently predicted, will be its fate.

C. E. C.

\section{CONTRIBUTION BETWEEN OWNERS OF WRONGFULLY PLEDGED SECURITIES}

The cases occasionally present the situation where contribution is exacted from persons subjected to a common burden from which they are freed at the expense of others in the same position; and with the increasing complexity of commercial organization its frequent recurrence may be expected. In the recent New York Case of Asylum of St. Vincent de Paul v. McGuire (1925) 239 N. Y. 375, 146 N. E. 632, several people deposited with a broker negotiable securities for safe-keeping. After wrongfully ${ }^{1}$ pledging them with a bank for a loan, the broker became bankrupt and the bank liquidated sufficient securities to recover its loan, the securities of a few, however, remaining intact. Reversing the trial judge, the court held that the remaining securities should be sold and a pro rata division of the proceeds be made among all the depositors.

In the few cases involving this same factual situation the courts have adopted two distinct views: first, that securities surviving the bank's claim may be recovered in full by their original owners without contribution $;^{2}$ and, second, that the remaining securities shall be subject to such contribution as will effect a pro rata distribution of the loss. ${ }^{3}$ The instant case represents the application of the second view, and is in accord with the

\footnotetext{
24 Professor Rothschild, the successful counsel in the instant case, has suggested that it is pressure of business which leads to the illiberal attitude on the part of the lower New York courts. (1925) 25 CoL. L. REv. 30,41 . It may be that the courts do hope to lighten their labors by disposing of the cases before them on short and narrow pleading grounds; but in the long run this can only serve to increase the congestion. Pressure of business ought to lead to less, rather than more, insistence on pleading technicalities.

1 For the duty owed by a broker to his principal, see (1925) 34 YALE LAW JOURNAT, 449.

2 In re McIntyre (1910, C. C. A. 2d) 181 Fed. 955; In ro McIntyro (1911, C. C. A. 2d) 189 Fed. 46; Johnson v. Birby (1918, C. C. A. 8th) 252 Fed. 103.

3 Gould v. Central Trust Co. (1879, Sup. Ct. Spec. T., N. Y.) 6 Abb. N. C. 381; McBride v. Potter-Lovell Co. (1897) 169 Mass. 7, 47 N. E.
} 